\title{
Level of Proficiency and Professional Development Needs in Peripheral Online Teaching Roles
}
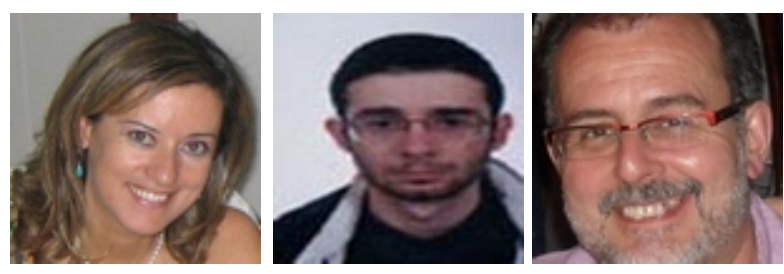

Mercedes González-Sanmamed ${ }^{1}$, Pablo-César Muñoz-Carril2, and Albert Sangrà ${ }^{3}$

1 Universidad de A Coruña, Spain, 2Universidad de Santiago de Compostela, Spain, ${ }^{3}$ Universitat Oberta de Catalunya, Spain

\section{Abstract}

Teaching in virtual environments demands mastery of several teaching competencies. Although the most accepted ones are pedagogical, in order to successfully teach online it becomes necessary to acquire and develop some other competencies, sometimes referred to as peripheral roles (Denis et al., 2004).

The aim of this study is to analyse perceptions on the level of proficiency that online teachers have regarding these peripheral roles (social, evaluator, manager, technologist, advisor/counsellor, personal, and researcher), and their professional development needs required to improve their online teaching competencies. A questionnaire was specifically created and validated by experts, and data was gathered from 166 university teachers.

The findings show that teachers highlight the importance of the peripheral roles for quality teaching, and thus, professional development programmes should be based on a balance between central and peripheral roles to better train online teachers and increase the quality of their teaching.

Keywords: Online teaching; professional development; peripheral roles; online learning environments; teaching competences 


\section{Introduction}

The use of information and communication technologies (ICT) for educational purposes has been widely adopted in the last decade (Bates \& Sangrà, 2011; Bullen \&J anes, 2007; Carr-Chelleman, 2005), and Higher Education institutions could not avoid their proliferation in universities. In such a context most of the universities have embraced online teaching and learning as a means of better serving their students by giving more flexibility to their programmes and providing blended or complementary courses. As a result of this growing interest and use, online education has finally been taken into account as a serious player in the field of Higher Education, including being used for attracting potential students.

No matter the initial reaction from the faculty at these institutions, the organization and the technologies of teaching in most of them have changed, and the culture of teaching itself has undergone significant adaptation (Lokken \& Womer, 2007; Sangrà \& González-Sanmamed, 2004).

The large number of available studies enables us to observe the enormous interest raised by the analysis of teaching skills, not only as a research issue, but also as a theoretical conceptualization. As importantly these studies have institutional, academic, and professional relevance in outlining the appropriate teacher's profile and characteristics needed to face online teaching functions as a benchmark for the design of professional development actions and plans. This article, in order to deal with the perspectives that have been mentioned, starts with a literature review to establish a list of competencies that undergo the judgment of teachers from a university that is starting a process of introduction of a blended learning mode offer, in order to identify their perceptions regarding their level of proficiency and their professional development needs, with the purpose of guiding training programmes that would improve their professional performance.

University teachers in particular are being challenged to obtain the necessary competencies to work in online environments. In contrast with other studies focused on the central pedagogical competency, this study is interested in ascertaining the level of proficiency that teachers perceive they have regarding the peripheral online teaching roles (Denis et al., 2004), and their willingness and need for professional development programmes aimed at broadening and improving their current level of proficiency.

\section{Literature Review}

Although there is agreement that online teaching demands different teaching tasks and skills (Major, 2010; Spector, 2007), two different approaches can be found when reviewing the current literature on the competencies online teachers need to have for performing effectively. On one hand, some authors argue that online teaching competencies are similar to those needed for face-to-face teaching (Bautista, Borges \& Forés, 2006). Conversely, others argue that some competencies are specific to online 
teaching, even if some others might seem quite similar (Ardizzone \& Rivoltella, 2004; Laat et al., 2007). Varvel (2007) contends that online teaching includes the creation of an effective learning environment using activities and resources that are dispersed, and this is not an easy task. Bawane and Spector (2009) pointed out that programme characteristics, the available resources and the role the teacher has to perform determine the competencies the teachers should acquire.

Muñoz-Carril, González-Sanmamed and Hernández-Sellés (2013) recently carried out a literature review of the roles required of the online teacher. In this previous work, two tables were drawn to classify and show the associated competencies to each of the roles of the online teacher identified by the reviewed authors. One table (Muñoz-Carril, González-Sanmamed and Hernández-Sellés, 2013, 466-467) synthesised the work carried out by each author, resulting in a framework summarising eight major roles required of online teachers. A second table pointed out the associated competencies related with the different roles (Muñoz-Carril, González-Sanmamed \& HernándezSellés, 2013, 469-470). This table was drawn after holding a focus group with online teachers in order to identify, based on practice, the competencies associated with each of these roles.

This initial literature review has been utilised as a starting point for this article, giving the appropriate framework for the study presented here. Despite the fact that most of the authors reviewed agree on the importance of all the roles, their publications have always given predominance to the pedagogical role (Bawane \& Spector, 2009). In the review carried out by Muñoz-Carril, González-Sanmamed and Hernández-Sellés (2013) they also highlight that the pedagogical role is most often mentioned in the literature.

These results are in line with the classical vision in which the main function of a teacher is to teach, and thus, for decades teaching has been identified with expository transmission of knowledge. Thus, teachers with extensive experience teaching face-toface who move to online teaching often have "the tendency of carrying traditional educational practices into the online environment" (Kreber \& Kanuka, 2006, 422). When approaching online education, teaching should assume another important function: to make students' learning easier by taking advantages and affordances of the new digital context (Anderson \& Elloumi, 2008) which involves significantly more roles than expository teaching.

In this virtual scenario, teaching becomes a complex task that requires teachers to possess and perform a diverse set of competencies associated with each role, and to make effective use of the resources and support that might be available (Bawane \& Spector, 2009). To do that, those functions that Denis et al. (2004) name peripheral roles are at least as important as the central pedagogical role.

The relevance of these peripheral roles is highlighted by some authors, who point out the aspects that could have a bigger influence on the process of enhancing learning. Authors such as Coppola, Hiltz and Rotter (2002), Varvel (2007), Bawane and Spector 
(2009), Guasch, Alvarez and Espasa (2010) and Baran, Correia and Thompson (2011) mention the importance of the social or affective role, regarding the relationships between students and the teacher, the ways that emotions could be expressed online, and how they can improve the online classroom atmosphere. They also consider the managerial or administrative role as one that demands great attention, because it involves establishing rules and regulations, carries out planned teaching actions, and requires student-monitoring. Varvel (2007) indicates that the administrative role also involves processes related to the proper functioning of the institutional process in the online context. He considers that these administrative rules, though in many ways unrelated to instructional competencies, are "nonetheless inclusive of knowledge that an instructor should have". These authors and others like Aydin (2005), Berge (1995), Egan and Akdere (2005), Salmon (2004), and Williams (2003) also emphasize the technological role, referring to the knowledge the teacher should have to adequately use the necessary technology and to find and integrate educational software, in addition to being able to solve small technical problems and provide some level of technical support to the students.

An evaluator role appears in the classification developed by Bawane and Spector (2009), Varvel (2007), and Egan and Akdere (2005), whose main functions are to provide feedback, grades and to acknowledge student performance, either individually or in groups. Aydin (2005) also adds to this providing students assurance of authenticity.

In the advisor/ counsellor role, Bawane and Spector (2009), and Aydin (2005) contend that the teacher helps the students to achieve the greatest benefit from their engagement with the course, providing guidance and measures to enhance their confidence and performance which may persist even beyond the end of the course.

Varvel (2007) adds a personal role that involves all the physical and mental abilities and their personality attributes, which are independent of the institution where they work. Teachers' personal beliefs and their vision and perception of teaching condition this role and thus influence the processes in which teachers are involved.

The research role focuses on creating new relevant knowledge, not only in the disciplines that the teacher is working in, but also on research into the improvement of online teaching (Goodyear et al., 2001). Furthermore selection, creation and use of online resources for gathering information on online learning, including the development of new theories, are expected (Aydin, 2005). In addition, conducting research on their own classroom teaching and integrating their research findings into their teaching practice are characteristics of this research role (Bawane \& Spector, 2009).

All the revised literature focused on the description of the online teaching competencies and roles, but mostly from a theoretical perspective. Methodologies used in these studies are mainly descriptive and using experts for defining which the competencies 
and the roles should be. Delphi techniques and experts workshop-based data gathering are the most utilized ones. They give a powerful insight on the issue, but the voice of the practitioner is generally missed. The present study asked directly to the teaching staff who is currently living the transition between a traditional full classroom-based and a blended model.

\section{Purpose of the Study}

The purpose of this study is to identify and analyse the perceptions on the level of proficiency that online teachers have regarding the peripheral roles of online teaching (social, evaluator, manager, technologist, advisor/ counsellor, personal, and researcher), and their professional development needs required to improve their online teaching competencies. Implications for professional development and for evaluation of online teaching performance might also be found.

\section{Study Context}

The context of the research is situated in A Coruña University (hereinafter UDC), a Spanish public university located in the north-west of the Iberian Peninsula. The university has 25 academic centres, offering 42 bachelor, 53 master, and $46 \mathrm{PhD}$ programmes. These programmes are supported by a total of 1,458 teachers ( 512 female; 946 male), with 19,581 bachelor students, 1,054 master students, and 1,362 $\mathrm{PhD}$ students enrolled.

The university traditionally provided face-to-face classes, but since 2000 has been moving to a blended learning mode integrating online teaching and learning in some of the programmes. The plans for implementing this evolution have been analysed and published (Bates \& Sangrà, 2011; González-Sanmamed, 2004). Through this transition to blended learning, the university has had to develop and implement a series of professional development activities.

Despite there is no single or unified understanding between all the UDC faculty on which is the theory underlying the term of online teaching, there are some commonalities regarding the concept. On one hand, online teaching is considered as an extension of their current teaching, that is, a good support for traditional lecture-based teaching. On the other hand, they envisage online teaching as a way for modernizing and improving the way in which they teach and their students learn. It is from this conception that they deal with the need of being provided with more professional development to take advantage of the potential of this new situation (GonzálezSanmamed, 2004; Bates \& Sangrà, 2011).

\section{Methodology}

The research method is a non-experimental quantitative survey (Cohen, Manion \& 
Morrison, 2007; McMillan \& Schumacher, 2005). An online questionnaire was designed and sent, via electronic means. The sample was accidental, applying a non-probabilistic technique survey (Cohen, Manion \& Morrison, 2007). The sample population was defined by the teaching staff practicing within the online teaching system from the A Coruña University. A census of teachers facilitated by the e-Learning Unit of the university was used to know how many teachers usually used the learning management system and carried out e-learning activities, and which was their disciplinary environment. A total amount of 628 subjects were identified, 399 belonging to the Science, Health, and Technical disciplinary environment, and 229 to the Socio-legal and the Humanities.

To allow these teachers to participate in the research, a letter was written inviting them to be a participant in the study by answering an attached questionnaire. This letter was sent through e-mail from the Vicerrectorate for Quality and European Harmonization. In addition, the same invitation letter was posted in the LMS to which all the teachers have access. After this process, a total of 166 valid questionnaires were gathered. Distribution of the respondents is shown in Table 1.

Table 1

Characteristics of the Sample Population Arranged by Categories: Administrative, Scientific Environment, and Teaching Experience within Virtual Learning Environments

\begin{tabular}{|c|c|c|c|c|c|c|c|c|c|}
\hline \multirow[t]{2}{*}{$\begin{array}{l}\text { Identification } \\
\text { variable }\end{array}$} & \multicolumn{2}{|c|}{$\begin{array}{l}\text { Administrative } \\
\text { category }\end{array}$} & \multicolumn{2}{|c|}{$\begin{array}{l}\text { Disciplinary } \\
\text { environment }\end{array}$} & \multicolumn{5}{|c|}{ Online teaching experience } \\
\hline & $\begin{array}{l}\text { Full } \\
\text { time } \\
\text { faculty }\end{array}$ & $\begin{array}{l}\text { Part } \\
\text { time } \\
\text { teachers }\end{array}$ & $\begin{array}{l}\text { Science. } \\
\text { Health, } \\
\text { and } \\
\text { Technical }\end{array}$ & $\begin{array}{l}\text { Social-legal } \\
\text { and } \\
\text { Humanities }\end{array}$ & $\begin{array}{l}\text { Less } \\
\text { than } \\
1 \\
\text { year }\end{array}$ & $\begin{array}{l}\text { Between } \\
1 \text { and } 2 \\
\text { years }\end{array}$ & $\begin{array}{l}\text { Between } \\
3 \text { and } 4 \\
\text { years }\end{array}$ & $\begin{array}{l}\text { Between } \\
5 \text { and } 6 \\
\text { years }\end{array}$ & $\begin{array}{l}\text { More } \\
\text { than } 6 \\
\text { years }\end{array}$ \\
\hline $\mathrm{N}$ & 107 & 59 & 104 & 62 & 26 & 37 & 55 & 17 & 25 \\
\hline$\%$ & 64.5 & 35.5 & 62.7 & 37.3 & 16.3 & 23.1 & 34.4 & 10.6 & 15.6 \\
\hline
\end{tabular}

This article outlines the results from one of the blocks within the questionnaire, analysing the teachers' self-perceived level of proficiency on the competencies of the online teaching peripheral roles, as well as their interest in increasing their professional development. Specifically, it outlines the results achieved regarding the peripheral roles, because the ones associated with the pedagogical role have already been published in another work (Muñoz-Carril, González-Sanmamed \& Hernández-Sellés, 2013). To build this block of the questionnaire, items were developed based on the competencies associated with each of the peripheral roles shown in Table 2 in that previous work (Muñoz-Carril, González-Sanmamed \& Hernández-Sellés, 2013). The first iteration of 
the items underwent a double process of validation through the judgement of six experts, and also through a pilot test, after which some items were altered. Tables 2 to 8 show the items developed to test subjects' perceptions of the aforementioned peripheral roles.

Each item is assessed on a 5-point Likert scale. This scale looks at teachers' perceptions, understanding 5 as the higher rate of their perceived level of proficiency and 1 as the lowest. Cronbach's alpha internal reliability index was then applied. The internal consistency coefficient obtained in the peripheral roles' competencies section was considerably higher. The category "level of proficiency" scored $\alpha=0.987$; and the category "professional development need" scored $\alpha=0.990$.

\section{Results}

As can be seen in Table 2, for the competencies associated with the social role, all the mean rank values related to the variable "professional development needs" (positive ranks) are higher than "level of proficiency". Particularly, it is interesting to note that teachers show a high professional development need for competencies such as "Encourage and stimulate positive participation in a friendly learning environment" (sum of ranks $=5505.00$ ).

On the other hand, for the median contrast carried out through Wilcoxon signed ranks test and shown in Table 2, the evidence suggests that there are significant differences in every social role for associated competencies between the two variables, "level of proficiency" and "professional development needs". The most significant differences taking into consideration the sum of ranks, are found in the competencies "Encourage and stimulate positive participation in a friendly learning environment" and "Streamlining training and online networking", which are very similar elements from a conceptual point of view. 
Table 2

Wilcoxon Signed Ranks Test. Median Difference on the Level of Proficiency and Professional Development Needs Regarding the Social Role Competencies Applied to Online Teaching

\begin{tabular}{|c|c|c|c|c|c|c|}
\hline & & & $\mathrm{N}$ & Mean rank & $\begin{array}{c}\text { Sum of } \\
\text { ranks }\end{array}$ & $\begin{array}{c}\text { Test } \\
\text { statistics }\end{array}$ \\
\hline \multirow{4}{*}{$\begin{array}{l}\text { 34-Encourage } \\
\text { and stimulate } \\
\text { positive } \\
\text { participation in a } \\
\text { friendly learning } \\
\text { environment }\end{array}$} & $\begin{array}{l}\text { Negative } \\
\text { ranks }\end{array}$ & 25 & 42.00 & 1050.00 & $\mathrm{Z}$ & $-6.392^{\mathrm{a}}$ \\
\hline & Positive ranks & 89 & 61.85 & 5505.00 & \multirow{3}{*}{$\begin{array}{l}\text { Asymp. } \\
\text { Sig. }\end{array}$} & \multirow[t]{3}{*}{.000} \\
\hline & Ties & 52 & & & & \\
\hline & Total & 166 & & & & \\
\hline \multirow{4}{*}{$\begin{array}{l}\text { 35-Suggest } \\
\text { activities to } \\
\text { facilitate } \\
\text { knowledge } \\
\text { development } \\
\text { amongst } \\
\text { participants }\end{array}$} & $\begin{array}{l}\text { Negative } \\
\text { ranks }\end{array}$ & 18 & 40.19 & 723.50 & $\mathrm{Z}$ & $-6.443^{a}$ \\
\hline & Positive ranks & 84 & 53.92 & 4529.50 & \multirow{3}{*}{$\begin{array}{l}\text { Asymp. } \\
\text { Sig. }\end{array}$} & \multirow[t]{3}{*}{.000} \\
\hline & Ties & 64 & & & & \\
\hline & Total & 166 & & & & \\
\hline \multirow{4}{*}{$\begin{array}{l}\text { 25-Give feedback } \\
\text { on student } \\
\text { interactions and } \\
\text { public and } \\
\text { private } \\
\text { recommendation } \\
\text { s on their work } \\
\text { and its quality }\end{array}$} & $\begin{array}{l}\text { Negative } \\
\text { ranks }\end{array}$ & 30 & 41.43 & 1243.00 & $\mathrm{Z}$ & $-4.252^{\mathrm{a}}$ \\
\hline & Positive ranks & 68 & 53.06 & 3608.00 & \multirow{3}{*}{$\begin{array}{l}\text { Asymp. } \\
\text { Sig. }\end{array}$} & \multirow[t]{3}{*}{.000} \\
\hline & Ties & 68 & & & & \\
\hline & Total & 166 & & & & \\
\hline \multirow{4}{*}{$\begin{array}{l}\text { 36-Streamlining } \\
\text { training and } \\
\text { online } \\
\text { networking }\end{array}$} & $\begin{array}{l}\text { Negative } \\
\text { ranks }\end{array}$ & 18 & 42.50 & 765.00 & $\mathrm{Z}$ & $-6.677^{a}$ \\
\hline & Positive ranks & 89 & 56.33 & 5013.00 & \multirow{3}{*}{$\begin{array}{l}\text { Asymp. } \\
\text { Sig. }\end{array}$} & \multirow[t]{3}{*}{.000} \\
\hline & Ties & 59 & & & & \\
\hline & Total & 166 & & & & \\
\hline \multirow{4}{*}{$\begin{array}{l}\text { 5-Summarize the } \\
\text { inputs from } \\
\text { students in group } \\
\text { discussions }\end{array}$} & $\begin{array}{l}\text { Negative } \\
\text { ranks }\end{array}$ & 19 & 37.68 & 716.00 & $\bar{Z}$ & $-6.375^{a}$ \\
\hline & Positive ranks & 82 & 54.09 & 4435.00 & \multirow{3}{*}{$\begin{array}{l}\text { Asymp. } \\
\text { Sig. }\end{array}$} & \multirow[t]{3}{*}{.000} \\
\hline & Ties & 65 & & & & \\
\hline & Total & 166 & & & & \\
\hline \multirow[t]{4}{*}{$\begin{array}{l}\text { 33-Integrate and } \\
\text { lead discussions }\end{array}$} & $\begin{array}{l}\text { Negative } \\
\text { ranks }\end{array}$ & 22 & 39.50 & 869.00 & $\mathrm{Z}$ & $-6.283^{a}$ \\
\hline & Positive ranks & 84 & 57.17 & 4802.00 & \multirow{3}{*}{$\begin{array}{l}\text { Asymp. } \\
\text { Sig. }\end{array}$} & \multirow[t]{3}{*}{.000} \\
\hline & Ties & 60 & & & & \\
\hline & Total & 166 & & & & \\
\hline
\end{tabular}

a. Based on negative ranks. 
With respect to the competencies associated with the evaluator role (see Table 3), and as happened in the case of the social role, higher mean rank scores appear for the variable "professional development needs" (positive ranks) than for "level of proficiency" (negative ranks) and involve significant differences bilaterally. These results make visible the teachers' interest in improving those aspects related to assessment processes in virtual teaching and learning environments.

Based on the data collected, the differences are particularly significant in the item concerning "Conduct evaluation practices" and "Keep the students Informed about their progress in the study".

Table 3

Wilcoxon Signed Ranks Test. Median Difference on the Level of Proficiency and Professional Development Needs Regarding the Evaluator Role Competencies Applied to Online Teaching

\begin{tabular}{|c|c|c|c|c|c|c|}
\hline & & $\mathrm{N}$ & \begin{tabular}{|l|} 
Mean \\
rank \\
\end{tabular} & \begin{tabular}{|l}
$\begin{array}{l}\text { Sum of } \\
\text { ranks }\end{array}$ \\
\end{tabular} & Test stat & \\
\hline $\begin{array}{l}\text { 26-Keep the students } \\
\text { informed about their }\end{array}$ & $\begin{array}{l}\text { Negative } \\
\text { ranks }\end{array}$ & 25 & 37.70 & 942.50 & $\mathrm{Z}$ & $-5.699 a$ \\
\hline progress in the study & $\begin{array}{l}\text { Positive } \\
\text { ranks }\end{array}$ & 77 & 55.98 & 4310.50 & Asymp. & \\
\hline & Ties & 64 & & & & .000 \\
\hline & Total & 166 & & & & \\
\hline $\begin{array}{l}\text { 4-Make global and } \\
\text { individual assessments }\end{array}$ & $\begin{array}{l}\text { Negative } \\
\text { ranks }\end{array}$ & 28 & 47.30 & 1324.50 & $\mathrm{Z}$ & $-4.615^{a}$ \\
\hline $\begin{array}{l}\text { of the activities carried } \\
\text { out }\end{array}$ & $\begin{array}{l}\text { Positive } \\
\text { ranks }\end{array}$ & 76 & 54.41 & 4135.50 & Asymp. & \\
\hline & Ties & 62 & & & & .000 \\
\hline & Total & 166 & & & & \\
\hline $\begin{array}{l}\text { 8-Conduct evaluation } \\
\text { practices }\end{array}$ & $\begin{array}{l}\text { Negative } \\
\text { ranks }\end{array}$ & 20 & $\begin{array}{l}40.9 \\
0 \\
\end{array}$ & 818.00 & $\mathrm{Z}$ & $-6.741^{\mathrm{a}}$ \\
\hline & $\begin{array}{l}\text { Positive } \\
\text { ranks }\end{array}$ & 90 & 58.74 & 5287.00 & Asymp. & \\
\hline & Ties & 56 & & & & .000 \\
\hline & Total & 166 & & & & \\
\hline $\begin{array}{l}\text { 2-Ensure that the } \\
\text { students meet course }\end{array}$ & $\begin{array}{l}\text { Negative } \\
\text { ranks }\end{array}$ & 33 & 46.73 & 1542.00 & $\mathrm{Z}$ & $-4.029 a$ \\
\hline objectives & $\begin{array}{l}\text { Positive } \\
\text { ranks }\end{array}$ & 72 & 55.88 & 4023.00 & Asymp. & \\
\hline & Ties & 61 & & & & .000 \\
\hline & Total & 166 & & & & \\
\hline
\end{tabular}

a. Based on negative ranks. 
Regarding the analyses of the competencies associated with the managerial role (see Table 4), the Wilcoxon test yields significant results in all the considered variables, except in the case of "Plan and manage the schedule of course events". The fact that it is quite easy, at the managerial level, to introduce in the learning content management system any key course event, as activities, news, tutoring hours, and so on can result in a lower perception of professional development needs in this competency.

Otherwise, we should highlight the relevance for teachers of improving their training in competencies related to those processes that can help them to improve the support they can provide to the students, such as "Manage efficiently the procedures for supporting students to work online". This is a basic issue, especially in those cases in which teachers tend to carry out collaborative learning activities, as well as in the case of "Perform a welcome protocol for the students participating in the online course, establishing rules and regulations", another key issue to improve the learning process.

Table 4

Wilcoxon Signed Ranks Test. Median Difference on the Level of Proficiency and Professional Development Needs Regarding the Managerial Role Competencies Applied to Online Teaching

\begin{tabular}{|c|c|c|c|c|c|c|}
\hline & & $\mathrm{N}$ & Mean & Sum of & Test stat & ics \\
\hline $\begin{array}{l}\text { 19-Plan and manage } \\
\text { the schedule of course }\end{array}$ & $\begin{array}{l}\text { Negative } \\
\text { ranks }\end{array}$ & 39 & 53.05 & 2069.00 & Z & $-1.119^{a}$ \\
\hline $\begin{array}{l}\text { events (activities, } \\
\text { assessment tests, }\end{array}$ & $\begin{array}{l}\text { Positive } \\
\text { ranks }\end{array}$ & 58 & $\begin{array}{l}46.2 \\
8\end{array}$ & 2684.00 & & \\
\hline discussions, tutoring, & Ties & 69 & & & $\begin{array}{l}\text { Asymp. } \\
\text { Sig. }\end{array}$ & .263 \\
\hline & Total & 166 & & & & \\
\hline $\begin{array}{l}\text { 31-Perform a welcome } \\
\text { protocol for the }\end{array}$ & $\begin{array}{l}\text { Negative } \\
\text { ranks }\end{array}$ & 21 & $\begin{array}{l}33.8 \\
8\end{array}$ & 711.50 & Z & $-6.991^{\mathrm{a}}$ \\
\hline $\begin{array}{l}\text { students participating } \\
\text { in the online course, }\end{array}$ & $\begin{array}{l}\text { Positive } \\
\text { ranks }\end{array}$ & 88 & $\begin{array}{l}60.0 \\
4\end{array}$ & 5283.50 & Asymp. & \\
\hline establishing rules and & Ties & 57 & & & & .000 \\
\hline regulations & Total & 166 & & & & \\
\hline $\begin{array}{l}\text { 20-Establish online } \\
\text { communication }\end{array}$ & $\begin{array}{l}\text { Negative } \\
\text { ranks }\end{array}$ & 29 & 47.79 & 1386.00 & Z & $-4.081^{a}$ \\
\hline $\begin{array}{l}\text { structures based on its } \\
\text { ease of use (usability }\end{array}$ & $\begin{array}{l}\text { Positive } \\
\text { ranks }\end{array}$ & 72 & 52.29 & 3765.00 & Asymp. & \\
\hline and information & Ties & 65 & & & & .000 \\
\hline architecture) & Total & 166 & & & & \\
\hline $\begin{array}{l}\text { 27-Perform as a } \\
\text { reference for students }\end{array}$ & $\begin{array}{l}\text { Negative } \\
\text { ranks }\end{array}$ & 27 & 37.19 & 1004.00 & Z & $-5.016^{a}$ \\
\hline $\begin{array}{l}\text { in the context of the } \\
\text { institution }\end{array}$ & $\begin{array}{l}\text { Positive } \\
\text { ranks }\end{array}$ & 70 & 53.56 & 3749.00 & Asymp. & \\
\hline & Ties & 69 & & & & .000 \\
\hline & Total & 166 & & & & \\
\hline
\end{tabular}




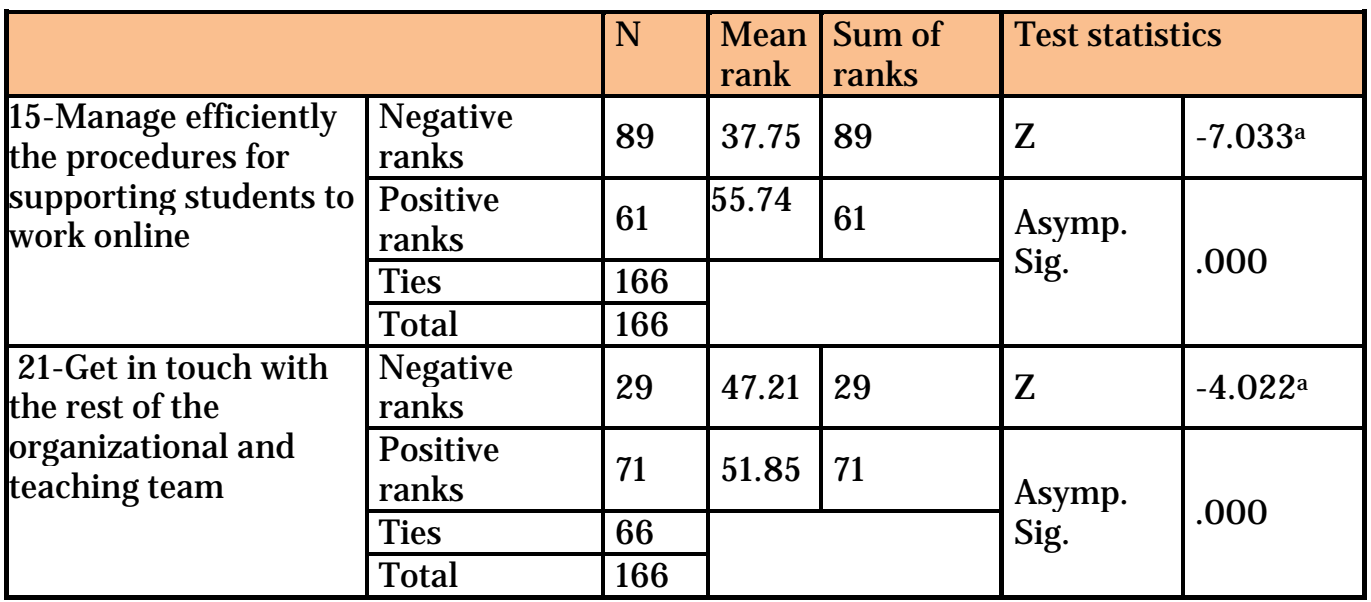

a. Based on negative ranks.

Related to the competencies associated with the technological role (see Table 5), the Wilcoxon signed ranks test indicates that there are significant differences between the "level of proficiency" and the "professional development needs". Among the several competencies associated with the technological role, the item which shows the highest difference, being highlighted over the other ones is: "Select and create multimedia educational resources meeting recognized standards in e-learning". This is likely linked to the fact that it sometimes becomes difficult to work with multimedia software to produce new digital resources, and also for the often-assumed association between "create digital content" and "teaching online".

Table 5

Wilcoxon Signed Ranks Test. Median Difference on the Level Of Proficiency and Professional Development Needs Regarding the Technological Role Competencies Applied to Online Teaching

\begin{tabular}{|c|c|c|c|c|c|c|}
\hline & \multirow{2}{*}{$\begin{array}{l}\mathrm{N} \\
27\end{array}$} & \multirow{2}{*}{\begin{tabular}{|l|}
$\begin{array}{l}\text { Mean } \\
\text { rank }\end{array}$ \\
39.67 \\
\end{tabular}} & \multirow{2}{*}{\begin{tabular}{|l}
$\begin{array}{l}\text { Sum of } \\
\text { ranks }\end{array}$ \\
1071.00
\end{tabular}} & \multicolumn{2}{|c|}{ Test statistics } \\
\hline \multirow{4}{*}{$\begin{array}{l}\text { 12-Become aware of } \\
\text { the use of the virtual } \\
\text { learning environment, } \\
\text { by carrying out specific } \\
\text { activities }\end{array}$} & $\begin{array}{l}\text { Negative } \\
\text { ranks }\end{array}$ & & & & $\mathrm{Z}$ & $-5.453^{a}$ \\
\hline & $\begin{array}{l}\text { Positive } \\
\text { ranks }\end{array}$ & 77 & 57.00 & 4389.00 & \multirow{3}{*}{$\begin{array}{l}\text { Asymp. } \\
\text { Sig. }\end{array}$} & \multirow{3}{*}{.000} \\
\hline & \begin{tabular}{|l} 
Ties \\
\end{tabular} & 62 & & & & \\
\hline & Total & 166 & & & & \\
\hline \multirow{4}{*}{$\begin{array}{l}\text { 10-Ensure that } \\
\text { students understand } \\
\text { the technical operation } \\
\text { of the virtual learning } \\
\text { environment }\end{array}$} & $\begin{array}{l}\text { Negative } \\
\text { ranks }\end{array}$ & 29 & 45.98 & 1333.50 & Z & $-3.677^{a}$ \\
\hline & $\begin{array}{l}\text { Positive } \\
\text { ranks }\end{array}$ & 67 & 49.59 & 3322.50 & \multirow{3}{*}{$\begin{array}{l}\text { Asymp. } \\
\text { Sig. }\end{array}$} & \multirow{3}{*}{.000} \\
\hline & Ties & 70 & & & & \\
\hline & Total & 166 & & & & \\
\hline
\end{tabular}




\begin{tabular}{|c|c|c|c|c|c|c|}
\hline & & $\mathrm{N}$ & Mean & Sum of & Test sta & \\
\hline $\begin{array}{l}\text { 11-Provide advice and } \\
\text { technical support }\end{array}$ & $\begin{array}{l}\text { Negative } \\
\text { ranks }\end{array}$ & 33 & 46.61 & 1538.00 & $\mathrm{Z}$ & $-3.450^{a}$ \\
\hline & $\begin{array}{l}\text { Positive } \\
\text { ranks }\end{array}$ & 67 & 52.42 & 3512.00 & Asymp. & \\
\hline & Ties & 66 & & & & .001 \\
\hline & Total & 166 & & & & \\
\hline $\begin{array}{l}\text { 17-Select and create } \\
\text { multimedia }\end{array}$ & $\begin{array}{l}\text { Negative } \\
\text { ranks }\end{array}$ & 9 & 41.83 & 376.50 & Z & $-8.321^{a}$ \\
\hline $\begin{array}{l}\text { educational resources } \\
\text { meeting recognized }\end{array}$ & $\begin{array}{l}\text { Positive } \\
\text { ranks }\end{array}$ & 106 & 59.37 & 6293.50 & Asymp. & \\
\hline standards in e-learning & Ties & 51 & & & & .000 \\
\hline & Total & 166 & & & & \\
\hline $\begin{array}{l}\text { 9-Suggest } \\
\text { modifications or new }\end{array}$ & $\begin{array}{l}\text { Negative } \\
\text { ranks }\end{array}$ & 31 & $\begin{array}{l}50.6 \\
6\end{array}$ & 1570.50 & $\mathrm{Z}$ & $-3.573^{a}$ \\
\hline $\begin{array}{l}\text { resources to be } \\
\text { included in the virtual }\end{array}$ & $\begin{array}{l}\text { Positive } \\
\text { ranks }\end{array}$ & 71 & 51.87 & 3682.50 & Asymp. & \\
\hline learning environment & Ties & 64 & & & & .000 \\
\hline & Total & 166 & & & & \\
\hline $\begin{array}{l}\text { 16-Stay up to date and } \\
\text { use proper software }\end{array}$ & $\begin{array}{l}\text { Negative } \\
\text { ranks }\end{array}$ & 18 & 45.36 & 816.50 & $\mathrm{Z}$ & $-6.437^{a}$ \\
\hline $\begin{array}{l}\text { needed for the } \\
\text { teaching process }\end{array}$ & $\begin{array}{l}\text { Positive } \\
\text { ranks }\end{array}$ & 88 & 55.16 & 4854.50 & Asymp. & \\
\hline & Ties & 60 & & & & .000 \\
\hline & Total & 166 & & & & \\
\hline $\begin{array}{l}\text { 14-Use synchronous } \\
\text { and asynchronous }\end{array}$ & $\begin{array}{l}\text { Negative } \\
\text { ranks }\end{array}$ & $20^{\text {s }}$ & 45.03 & 900.50 & $\mathrm{Z}$ & $-5.089 a$ \\
\hline $\begin{array}{l}\text { communication tools } \\
\text { in a proper way }\end{array}$ & $\begin{array}{l}\text { Positive } \\
\text { ranks }\end{array}$ & $74^{\mathrm{t}}$ & 48.17 & 3564.50 & Asymp. & \\
\hline & Ties & $72^{\mathrm{u}}$ & & & & .000 \\
\hline & Total & 166 & & & & \\
\hline $\begin{array}{l}\text { 13-Keep in touch with } \\
\text { your system }\end{array}$ & $\begin{array}{l}\text { Negative } \\
\text { ranks }\end{array}$ & $15^{v}$ & 44.53 & 668.00 & $\mathrm{Z}$ & $-6.480^{\mathrm{a}}$ \\
\hline administrator & $\begin{array}{l}\text { Positive } \\
\text { ranks }\end{array}$ & $85^{w}$ & 51.55 & 4382.00 & Asymp. & مח \\
\hline & Ties & $66^{\mathrm{x}}$ & & & & .000 \\
\hline & Total & 166 & & & & \\
\hline
\end{tabular}

A. Based on negative ranks.

Regarding the competencies associated with the advisor role, significant differences were detected after application of the Wilcoxon signed ranks test (see Table 6). Some competencies such as "Facilitate intellectual work techniques for networked studying" or "Provide guidance based on student needs" stood out because of its high positive rank in front of its negative one. This means a strong need from the teachers of improving their professional development in such issues. 
Table 6

Wilcoxon Signed Ranks Test. Median Difference on the Level Of Proficiency and Professional Development Needs Regarding the Advisor Role Competencies Applied to Online Teaching

\begin{tabular}{|c|c|c|c|c|c|c|}
\hline & & $\mathrm{N}$ & Mean & Sum of & Test stat & \\
\hline $\begin{array}{l}\text { 29-Ensure that } \\
\text { students work at an }\end{array}$ & $\begin{array}{l}\text { Negative } \\
\text { ranks }\end{array}$ & 26 & 41.52 & 1079.50 & $\mathrm{Z}$ & $-5.134^{a}$ \\
\hline $\begin{array}{l}\text { appropriate pace and } \\
\text { suggest measures to }\end{array}$ & $\begin{array}{l}\text { Positive } \\
\text { ranks }\end{array}$ & 75 & 54.29 & 4071.50 & Asymp. & \\
\hline enhance performance & Ties & 65 & & & Sig. & .000 \\
\hline & Total & 166 & & & & \\
\hline $\begin{array}{l}\text { 28-Provide guidance } \\
\text { based on student }\end{array}$ & $\begin{array}{l}\text { Negative } \\
\text { ranks }\end{array}$ & 38 & 45.20 & 1717.50 & $\mathrm{Z}$ & $-3.933^{a}$ \\
\hline needs & $\begin{array}{l}\text { Positive } \\
\text { ranks }\end{array}$ & 71 & 60.25 & 4277.50 & Asymp. & \\
\hline & Ties & 57 & & & & .000 \\
\hline & Total & 166 & & & & \\
\hline $\begin{array}{l}\text { 22-Provide meaningful } \\
\text { information about the }\end{array}$ & $\begin{array}{l}\text { Negative } \\
\text { ranks }\end{array}$ & 23 & 39.76 & 914.50 & $\mathrm{Z}$ & $-4.628 \mathrm{a}$ \\
\hline institution & $\begin{array}{l}\text { Positive } \\
\text { ranks }\end{array}$ & 67 & 47.47 & 3180.50 & Asymp. & \\
\hline & Ties & 76 & & & & .000 \\
\hline & Total & 166 & & & & \\
\hline $\begin{array}{l}\text { 1-Reply to students' } \\
\text { work (offer advice, }\end{array}$ & $\begin{array}{l}\text { Negative } \\
\text { ranks }\end{array}$ & 36 & 51.71 & 1861.50 & $\mathrm{Z}$ & $-3.367 a$ \\
\hline $\begin{array}{l}\text { suggestions, and } \\
\text { clarify doubts) }\end{array}$ & $\begin{array}{l}\text { Positive } \\
\text { ranks }\end{array}$ & 72 & 55.90 & 4024.50 & Asymp. & \\
\hline & Ties & 58 & & & & .001 \\
\hline & Total & 166 & & & & \\
\hline 30-Motivate students & $\begin{array}{l}\text { Negative } \\
\text { ranks }\end{array}$ & 29 & $\begin{array}{l}45.9 \\
0\end{array}$ & 1331.00 & $\mathrm{Z}$ & $-4.166^{\mathrm{a}}$ \\
\hline & $\begin{array}{l}\text { Positive } \\
\text { ranks }\end{array}$ & 71 & 52.38 & 3719.00 & Asymp. & \\
\hline & Ties & 66 & & & & .000 \\
\hline & Total & 166 & & & & \\
\hline $\begin{array}{l}\text { 24-Facilitate } \\
\text { intellectual work }\end{array}$ & $\begin{array}{l}\text { Negative } \\
\text { ranks }\end{array}$ & 17 & 35.94 & 611.00 & $\mathrm{Z}$ & $-7.103^{a}$ \\
\hline $\begin{array}{l}\text { techniques for } \\
\text { networked studying }\end{array}$ & $\begin{array}{l}\text { Positive } \\
\text { ranks }\end{array}$ & 89 & 56.85 & 5060.00 & Asymp. & \\
\hline & Ties & 60 & & & & .000 \\
\hline & Total & 166 & & & & \\
\hline
\end{tabular}

a. Based on negative ranks.

As for the competencies associated with the personal and the researcher roles (see Tables 7 and 8), and following the trend of data presented in the preceding lines, significant contrasts between the level 
of proficiency" and "professional development need " are found again. Among the competencies associated with the personal role, it is interesting to note that "Adapt educational content to accessibility standards, and to ethic and legal requirements" scores significantly low with regard to "level of proficiency" (see negative ranks), while for the "professional development needs" it scores much higher (see positive ranks). This leads us to question the importance for teachers of adapting to teaching situations with high level of diversity, and with compliance with the ethical codes in their profession.

Table 7

Wilcoxon Signed Ranks Test. Median Difference on the Level of Proficiency and Professional Development Needs Regarding the Personal Role Competencies Applied to Online Teaching

\begin{tabular}{|c|c|c|c|c|c|c|}
\hline & \multirow{2}{*}{$\begin{array}{l}\mathrm{N} \\
12\end{array}$} & \multirow{2}{*}{\begin{tabular}{|l|}
$\begin{array}{l}\text { Mean } \\
\text { rank }\end{array}$ \\
49.71 \\
\end{tabular}} & \multirow{2}{*}{\begin{tabular}{|l|}
$\begin{array}{l}\text { Sum of } \\
\text { ranks }\end{array}$ \\
596.50
\end{tabular}} & \multicolumn{2}{|c|}{ Test statistics } \\
\hline \multirow{4}{*}{$\begin{array}{l}\text { 18-Adapt educational } \\
\text { content to accessibility } \\
\text { standards, and to ethic } \\
\text { and legal requirements }\end{array}$} & \begin{tabular}{|l|} 
Negative \\
ranks
\end{tabular} & & & & Z & $-7.448^{a}$ \\
\hline & $\begin{array}{l}\text { Positive } \\
\text { ranks }\end{array}$ & 99 & 56.76 & 5619.50 & \multirow{3}{*}{\begin{tabular}{|l} 
Asymp. \\
Sig. (2- \\
tailed)
\end{tabular}} & \multirow{3}{*}{.000} \\
\hline & \begin{tabular}{|l} 
Ties \\
\end{tabular} & 55 & & & & \\
\hline & \begin{tabular}{|l} 
Total \\
\end{tabular} & 166 & & & & \\
\hline \multirow{4}{*}{$\begin{array}{l}\text { 32-Encourage students } \\
\text { to exchange ideas and } \\
\text { discuss with peers } \\
\text { online }\end{array}$} & $\begin{array}{l}\text { Negative } \\
\text { ranks }\end{array}$ & 23 & 37.13 & 854.00 & $\mathrm{Z}$ & $-6.731^{a}$ \\
\hline & $\begin{array}{l}\text { Positive } \\
\text { ranks }\end{array}$ & 88 & \begin{tabular}{|l|}
60.9 \\
3 \\
\end{tabular} & 5362.00 & \multirow{3}{*}{$\begin{array}{l}\text { Asymp. } \\
\text { Sig. (2- } \\
\text { tailed) }\end{array}$} & \multirow{3}{*}{.000} \\
\hline & \begin{tabular}{|l} 
Ties \\
\end{tabular} & 55 & & & & \\
\hline & Total & 166 & & & & \\
\hline \multirow{4}{*}{$\begin{array}{l}\text { 23-Collaborate with } \\
\text { experts to strengthen } \\
\text { the potential of } \mathrm{e}- \\
\text { learning }\end{array}$} & $\begin{array}{l}\text { Negative } \\
\text { ranks }\end{array}$ & 22 & 33.48 & 736.50 & Z & $-5.789^{a}$ \\
\hline & $\begin{array}{l}\text { Positive } \\
\text { ranks }\end{array}$ & 73 & 52.38 & 3823.50 & \multirow{3}{*}{$\begin{array}{l}\text { Asymp. } \\
\text { Sig. (2- } \\
\text { tailed) }\end{array}$} & \multirow{3}{*}{.000} \\
\hline & Ties & 71 & & & & \\
\hline & Total & 166 & & & & \\
\hline
\end{tabular}

a. Based on negative ranks. 
Table 8

Wilcoxon Signed Ranks Test. Median Difference on the Level of Proficiency and Professional Development Needs Regarding the Researcher Role Competencies Applied to Online Teaching

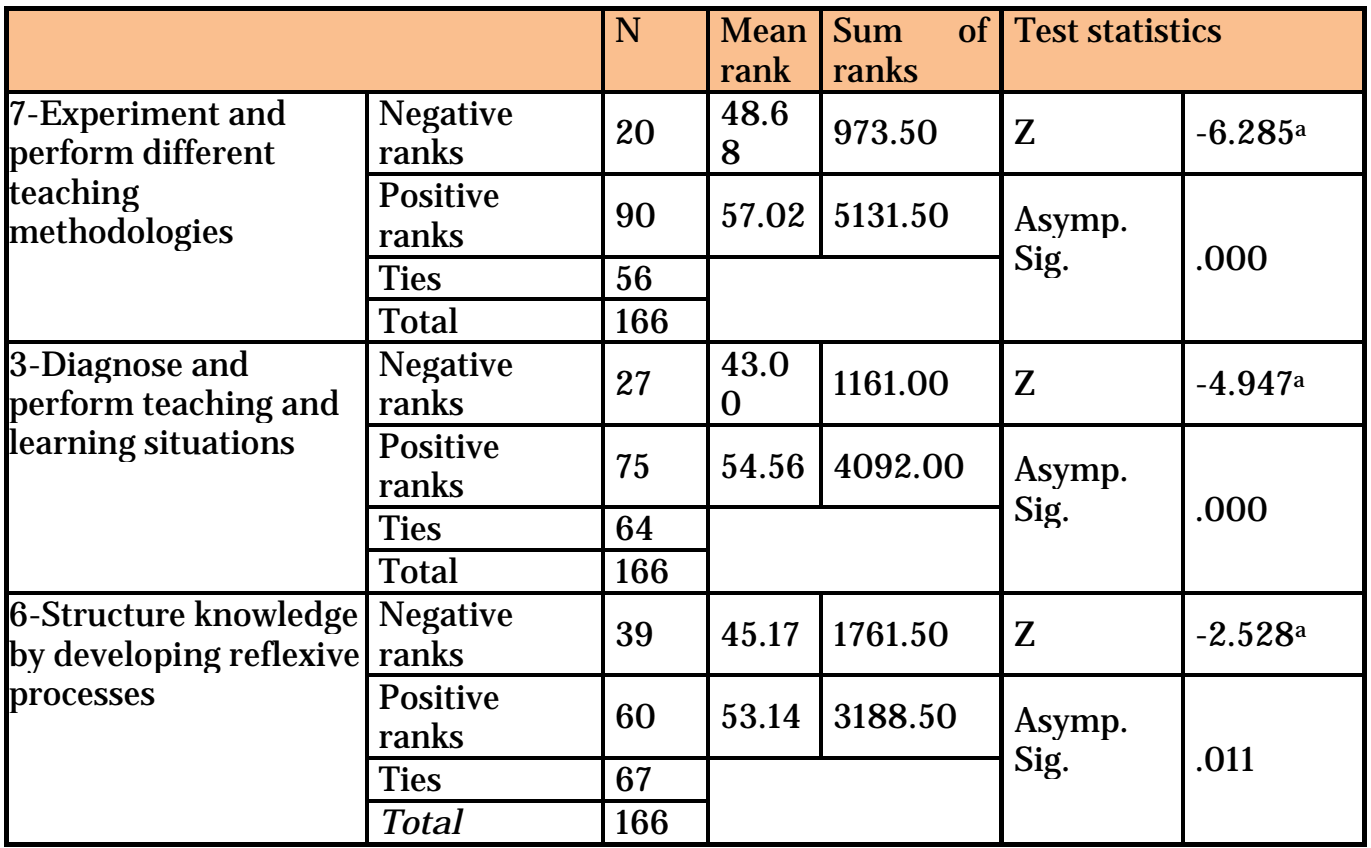

a. Based on negative ranks.

Finally, all the competencies have been grouped considering the role they belong to. In all cases, the Wilcoxon test informs that significant differences between "level of proficiency" and "professional development needs" exist. Scores achieved through "positive ranks" show that teachers confer a particular importance to the social, technological, and advisor roles, regarding their professional development needs.

A point of particular interest is the contrast of significant differences between professional variables, such as administrative category, disciplinary environment, and the online teaching experience. With regard to the professional development needs of university teachers and the different competencies associated with the online teaching peripheral roles, the conducted nonparametric tests have shown significant results, except for the variable "disciplinary environment". The Socio-legal and the Humanities fields are the ones that have shown higher professional development needs, in front of the Science, Health and Technical fields that scored lower. 
Another relevant question was to find out how the variable "professional development needs" influenced the "level of proficiency" in online teaching in the university setting. Analysis for each of the roles showed out a moderate direct and positive correlation. The highest coefficient was achieved by the "researcher" role (0.636).

Calculations for the set of all the roles also reveal that there is a positive (or direct) correlation (0.536), which is moderate. This allows us to reject the null hypothesis and to conclude that the variables are correlated in the population from which the sample comes (Figure 1).

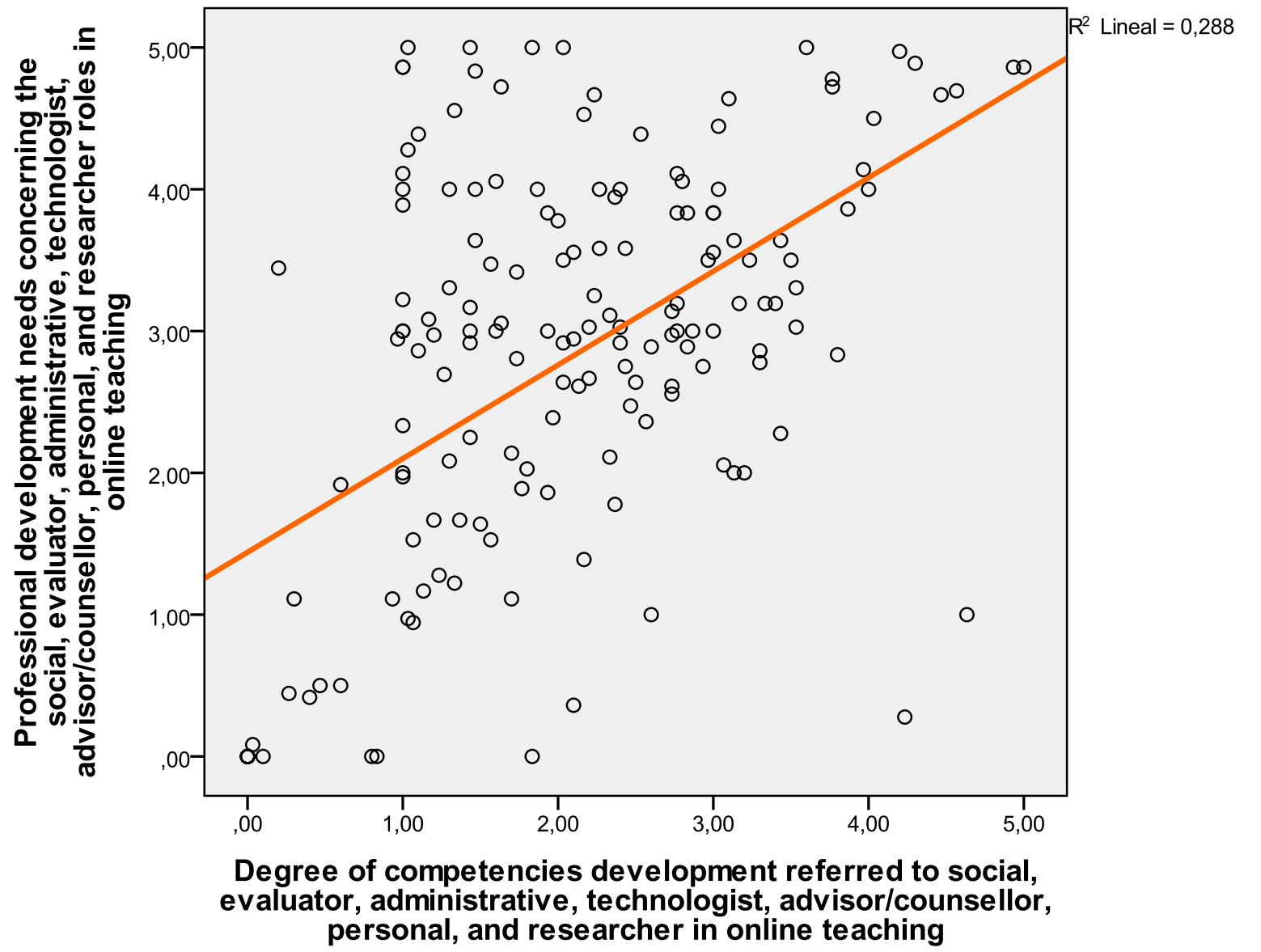

Figure 1. Scatter plot with regression line.

Thus, given the existence of linear correlation $(r>0.3$ and $p$ associated with the contrast of the correlation $<0.05$ ), statistical analysis was completed using a simple linear regression analysis to evaluate the relationship and estimate a regression line that could allow for making predictions. 
In the simple linear regression model, the coefficient of determination ( $\mathrm{R}$ squared) indicates that $28.8 \%$ of the variability in online teaching professional development needs is associated with the level of proficiency in the required competencies.

An ANOVA hypothesis testing for regression, which separates the variability explained by the regression and the unexplained or residual variability, was carried out. The results are statistically significant ( $p<0.001$ ), so there is an association between the two variables through linear regression.

A second inferential approach provides the coefficients of the model: the constant ( $\left.\beta_{0}=1,440\right)$ or value of the intercept, and the regression coefficient $\left(\beta_{1}=0,661\right.$ ) or slope of the line. These regression coefficients resulted significant ( $p$-value $=0,000$ ).

The resulting equation is:

$Y_{i=} \beta_{0}+\beta_{1} X_{1}$

Professional development needs $=1,440+(0,661$ Level of proficiency)

In summary, the analyses show that the higher the online teaching competency performance levels, the higher the professional development needs.

\section{Discussion and Conclusions}

The present study aims to widen the current available knowledge on online teaching. Both the theoretical background and the practical approach brought to light by teachers' perception of the level of proficiency and their professional development needs regarding the peripheral - and usually forgotten - online teaching roles contribute to this body of knowledge.

Competencies associated with online teaching roles are much more specific than those related to general teaching. At the same time, depending on the context and the situation, a competency could be perceived as being more important than another, and to have a large number of competencies may be necessary (Bawane \& Spector, 2009). In fact, teachers can have sets of competencies with different levels of proficiency between them. Proficiency refers to the levels of achievement of a particular competency. Most competency models have four or five levels of proficiency, from basic understanding to expert level. Some authors (Russ-Eft et al., 2008; Klein et al., 2004) have done research into establishing standards of performance as a means of considering the expected task to be developed by the teachers. This research has only been based on the self-perceived level of competency the teachers said they had. It is important to make the faculty aware of their basic and previous knowledge in order to build on the new one (Borko \& 
Putnam, 1996). Self-awareness is the starting point for self-demanding an increase in the knowledge and performance of any particular function and role (J oinson, 2001).

The findings show that when values in the variable "professional development needs" increase, higher values are also obtained for the variable "level of proficiency of competencies". The more training teachers have, the more aware they are of their skillsgap for each one, which makes the professional even more demanding.

However, significant mean differences have been found between teachers from the Socio-legal and Humanities disciplines, and the ones from the Science, Health and Engineering. The former demands more professional development opportunities regarding online teaching than the latter. This matches with the existence of intellectual clusters or styles of intellectual inquiry stated by Kolb (1981) and developed by Becher (1994), where Humanities and Social Sciences belongs to the concrete reflexive cluster, and the other ones to the abstract active cluster.

Even though most of the literature on online teaching roles focuses on the pedagogical role, peripheral roles are highly considered by the teachers, thus stressing the fact that online teaching needs an inclusive approach (Guasch, Alvarez \& Espasa, 2010).

For the evaluator role, it becomes clear that assessment and the processes around it are a fundamental pillar about which students can ascertain the level of learning they have achieved. But building complex assessment mechanisms that could be consistent with socio-constructivist-based teaching models requires teachers to have clear learning design principles, to design student-centred assessment activities, and to encourage self-reflection (Pallof \& Pratt, 2008).

The administrative role takes care of the management of the course and all the issues related to pedagogy. Teachers have clearly understood the importance of course planning, organizing, leading, and management (Coppola, Hiltz \& Rotter, 2002), as well as establishing rules and regulations for the proper development of the course, acting as the interface with the institution (Goodyear et al., 2001).

As for the advisor/ counsellor role, teachers feel the need to be better trained on "reply to students' work" as a means to improve the advisor's role. Tasks such as provide advice, give suggestions, and clarify doubts are highly valued (mean=3.02). This highlights the professional development need for feedback provision strategies, a line of work well defined by several authors (Espasa \& Meneses, 2010; Espasa, Guasch \& Alvarez, 2013). Likewise, students' motivations arise as another important task in this role (mean= 2.97). Both feedback provision strategies and students' motivation are very relevant issues in face-to-face teaching situations as well. But when considering online teaching as teaching at a distance, it becomes particularly important in pure distance education systems, which are usually criticised because of their high drop-out rates (Park \& Choi, 2009; Pierrakeas et al., 2004). 
Online education is inseparably linked to technology. But this doesn't mean that the online teaching role of technologist will have to necessarily be assumed by technology experts. Specific technology competencies for online teachers will vary depending on the mode of delivery of instruction to distance students (Williams, 2003). This explains teachers' continuous interest in being trained in technology. The knowledge of basic technology competencies is crucial, and to know how new technologies can influence online teaching in the very next future is a must. However, the training of technology competences should not be separate from those related to other online teaching roles. As stated by Mishra and Koehler (2006), teachers need a more integrated and multidimensional knowledge.

Personal and researcher roles are the ones less perceived by online teachers. In both cases, they ask for more professional development in these areas, probably because they are not very aware that these roles exist for online teaching, and they would like to strengthen these roles. Action research is usually conducted by some online teachers, integrating their research findings in their teaching (Bawane \& Spector, 2009).

However, the current faculty professional development programmes at the universities don't seem to adequately consider the research and the literature regarding online teaching roles and competencies (Baran, Correia \& Thompson, 2011; Sangrà, GonzálezSanmamed \& Romeu, 2013).

The results of this study, and especially the way teachers call for a more focused professional development on online teaching, could help to make people and institutions aware that online teaching goes beyond the simple fact of transferring the usual classroom-based teaching behaviour into another dimension by just using a different means of delivery. Understanding the different roles and tasks in an online teaching and learning environment is crucial for the evolution of institutions in the future. As stated by Painter (2003), institutions could construct barriers to acknowledging the success of teachers by not reflecting on everything involved in online teaching and ignoring the teachers' professional development needs.

In addition, those current programmes that are sensitive to the professional development needs are usually led to focus on planning and designing, or on introducing technical resources into teaching (Alvarez, Guasch \& Espasa, 2009; Turner, 2005), forgetting the above mentioned peripheral roles. As suggested by Baran, Correia and Thompson (2011), the literature suggests that the proposed roles and competencies of online teachers are useful in the curriculum, training, professional development of online teachers (Bawane \& Spector, 2009; Williams, 2003). This means that there should be significant efforts in carrying out inclusive professional programmes for online teaching.

The use of social networks in online education can also strengthen the development of the peripheral roles - especially those related to social roles (community, interactivity, teamwork) - which could become key for the improvement of online teaching 
performance (Singleton, 2004, also quoted by Bawane \& Spector, 2009). Berge (2008) calls to analyze how new emergent technologies and its use in online teaching could affect the need for a permanent revision of the competencies, roles and professional development need of online teachers.

\section{Implications for Future Development}

The results of this study envisage three main fields in which strong implications can be found.

The first one regards teacher training/professional development. The study shows teachers ask for more professional development in the so-called peripheral roles. As stated by Baran, Correia and Thompson (2011), specialized training related to each of the competences is needed. Higher levels of proficiency could be achieved through training and experience, so institutions should put in practice different programmes to increase the capacity of teachers to become good online teachers. Considering the above, it is logical that online training for teachers is necessary to efficiently teach in online environments (Mcdonald \& Poniatowska, 2011).

These programmes should consider both the central and the peripheral roles, and take into account the professional development needs that teachers have made evident. The balance between the roles is important, in order not to bias in a particular one (i.e., technology, which will continue to change quickly). In fact, technology should always support pedagogy, and it should be integrated in any of the approaches teachers adopt in their teaching.

The second one relates to the evaluation of online teaching performance. Deeper understanding of the whole set of roles online teachers have to carry out might be very useful for improving the way in which online teaching is going to be evaluated. Most of the current online teaching evaluation models focus mainly on the whole course (materials and resources, and on students' satisfaction), resulting in a sort of guidelines more than in actual online teaching assessment. Evolution of this issue since Chickering and Gamson (1987) has been relatively scarce.

And the third one faces the transformation of universities. The transition of moving from traditional classroom-based models to blended and online learning is becoming a critical point in the transformation of universities. In this process the three main elements that conform to the TOP triangle for an appropriate online education model implementation, technology, pedagogy and organization, should be strongly considered (Bates \& Sangrà, 2011). They cannot be considered separately, but strongly linked and influencing each other. Future research will have to focus on the collective transformations occurring in the institutions in which the individuals are very important agents (Baran, Correia \& Thompson, 2011). The peripheral roles of online teaching and its training programmes are an important part of this triangle, especially affecting organization and pedagogy. 
This research has been an attempt to highlight the online teaching dimensions that are not usually addressed by the current teacher training practices. To be aware about what the online teachers say from their practitioners' role will result of great usefulness, especially considering the importance that teaching staff has regarding the process of integration of online teaching in blended models.

Despite this study was conducted in a specific context, but the characteristics of a classroom-based institution which was in the process of incorporating online courses might be of interest because their issues and the implemented solutions may be transferable to other institutions given the interest of higher education institutions to incorporate technology and to design and implement online teaching ... "It is critical to gain access to the perspectives of teachers in examining the transformation" (Baran, Correia \& Thompson, 2011, 435). This is one of the contributions of this study, getting the data gathering closer to the teachers' practice and reflection. 


\section{References}

Alvarez, I., Guasch, T., \&Espasa, A. (2009). University teacher roles and competencies in online learning environments: A theoretical analysis of teaching and learning practices. European J ournal of Teacher Education, 32(3), 321-336.

Anderson, T., \&Elloumi, F. (Eds.) (2008). Theory and practice of online learning (Second Edition). Athabasca University Press, Athabasca. Retrieved July 16, 2013 from http://cde.athabascau.ca/online_book/second_edition.html

Ardizzone, P., \& Rivoltella, P.C. (2004). E-learning. Métodos e instrumentos para la innovación de la enseñanza universitaria. Málaga: Aljibe.

Aydin, C. (2005). Turkish mentors' perception of roles, competencies and resources for online teaching. Turkish Online J ournal of Distance Education, 6(3). Retrieved from http://tojde.anadolu.edu.tr/tojde19/articles/caydin.htm

Baran, E., Correia, A.P., \& Thompson, A. (2011). Transforming online teaching practice: Critical analysis of the literature on the roles and competencies of online teachers. Distance Education, 32(3), 421-439.

Bates, A.W. (Tony) \& Sangrà, A. (2011). Managing technology in higher education. Strategies for transforming teaching and learning. San Francisco: J osseyBass.

Bautista, G., Borges, F., \& Forés, A. (2006). Didáctica universitaria en entornos virtuales de enseñanza-aprendizaje. Madrid: Narcea.

Bawane, J ., \& Spector, M. (2009). Prioritization of online instructor roles: Implications for competency-based teacher education programs. Distance Education, 30(3), 383-397.

Berge, Z.L. (2008). Changing instructor's roles in virtual worlds. Quarterly Review of Distance Education, 9(4), 408-414.

Becher, T. (1994). The significance of disciplinary differences. Studies in Higher Education, 19(2), 151-161.

Borko, H., \& Putnam, R. T. (1996). Learning to teach. In D. C. Berliner \& R. C. Calfee (Eds.), Handbook of educational psychology (pp. 673-708). New York: Macmillan.

Bullen, M. \&J anes, D. (eds.) (2007). Making the transition to elearning: Strategies and issues. Hershey, PA: Idea Group. 
Carr-Chelleman, A.A. (2005). Global perspectives on e-learning: Rhetoric and reality. Thousand Oaks, CA: Sage.

Chickering, A., \& Gamson, Z. (1987). Seven principles of good practice in undergraduate education. AAHE Bulletin, 39, 3-7.

Cohen, L., Manion, L., \& Morrison, K. (2007). Research ethods in education. $6^{\text {th }}$ Edition. Routledge, New York.

Coppola, N., Hiltz, S., \& Rotter, N. (2002). Becoming a virtual professor: Pedagogical roles and asynchronous learning networks. J ournal of Management Information Systems, 18(4), 169- 189. Retrieved 10th J anuary 2012 from http:// www.jmis-web.org/ toppage/index.html

Denis, B., Watland, P., Oirotte, S., \& Verday, N. (2004). Role and competencies of the eTutor. In Proceedings of the Networked Learning Conferece 2004. Retrieved April 25, 2013, from http:// www.networkedlearningconference.org.uk/ past/nlc2004/ proceedi ngs/symposia/simposium6/denis_et_al.htm

Egan, T.M., \&Akdere, M. (2005). Clarifying distance education roles and competencies: Exploring similarities and differences between professional and studentpractitioner perspectives. American J ournal of Distance Education, 19(2), 87103. doi: 10.1207/s15389286ajde1902_3.

Espasa, A. \& Meneses, J . (2010). Analysing feedback processes in an online teaching and learning: An exploratory study. Higher Education, 59(3), 277-292.

Espasa, A., Guasch, T., \&Álvarez, I. (2013). Analysis of feedback processes in online group interaction: a methodological model. Digital Education Review, 23, 5973.

Gonzalez-Sanmamed, M. (2004). La integración de las TIC en la UDC: el proyecto ITEM. In Sangrá, A. \& González-Sanmamed, M. (Eds.). La transformación de las universidades a través de las TIC: discursos y prácticas. Barcelona: UOC, 121-126

Goodyear, P., Salmon, G., Spector, M., Steeples, C., \&Tickner, S. (2001). Competences for online teaching: A special report. Educational Technology Research and Development, 49, 1, 65- 72.

Guasch, T., Alvarez, I., \& Espasa, A. (2010). University teacher competencies in a virtual teaching / learning environment: Analysis of a teacher training experience. Teaching and Teacher Education, 26(2), 199- 206.

doi:10.1016/j.tate.2009.02.018 
J oinson, A.N. (2001). Self-disclosure in computer-mediated communication: The role of self-awareness and visual anonymity. European J ournal of Social Psychology, 31, 177-192.

Klein, J .D., Spector, J .M., Grabowski, B., \& De la Teja, I. (2004). Instructor competencies. Standards for face-to-face, online, and blended settings. $3^{\text {rd }}$. edition. Charlotte, NC: Information Age Publishing.

Kolb, D.A. (1981). Learning styles and disciplinary differences, in Chickering, A. (Ed.) The modern American college. San Francisco, CA: J ossey Bass.

Kreber, C. \& Kanuka, H. (2006). The scholarship of teaching and learning and the online classroom. Canadian J ournal of University Continuing Education, 32(2), 109- 131. Retrieved from http:// www.ccde.usask.ca/ cjuce/ articles/ v32pdf/ 3225.pdf (accessed 08 August 2013).

Laat, M., Lally, V., Lipponen, L., \& Simons, R. (2007). Online teaching in networked learning communities: A multi-method approach to studying the role of the teacher. Instructional Science, 35(3), 257- 286.

Lokken, F. \&Womer, L. (2007). Trends in e-learning: Tracking the impact of elearning in higher education. Washington, DC: Instructional Technology Council.

Macdonald, J . \& Poniatowska, B. (2011). Designing the professional development of staff for teaching online: An OU (UK) case study. Distance Education, 32(1), 119-134.

Major, C. (2010). Do virtual professors dream of electric students? College faculty experiences with online distance education. Teachers College Records, 112(8), 2154-2208.

Mishra, P. \& Koehler, M. J . (2006). Technologial pedagogical content knowledge: A new framework for teacher knowledge. Teachers College Record, 108(6), 1017-1054.

Mcmillan, J . \& Schumacher, S. (2005). Investigación educativa. Madrid: Pearson Addison Wesley.

Muñoz-Carril, P.C., González-Sanmamed, M. \& Hernández-Sellés, N. (2013). Pedagogical roles and competencies of university teachers practicing in the elearning environment. The International Review Of Research In Open And Distance Learning, 14(3), 462-487. Retrieved December 20, 2013, from http:// www.irrodl.org/index.php/irrodl/article/view/ 1477/ 2586 
Painter, L. A. (2003). Faculty attitudes toward online teaching and learning. Unpublished master's thesis. Victoria, Canada: Royal Roads University.

Palloff, R. M. \& Pratt, K. (2008). Assessing the online learner: Resources and strategies for faculty. San Francisco: J ossey-Bass.

Park, J .-H. \& Choi, H. J . (2009). Factors influencing adult learners' decision to drop out or persist in online learning. Educational Technology and Society, 12(4), 207217.

Pierrakeas, C., Xenos, M., Panagiotakopoulos, C., \&Vergidis, D. (2004). A comparative study of drop out rates for two different distance education courses. The International Review of Research in Open and Distance Learning (IRRODL), 5(2). Retrieved J uly 13, 2013, from http:/ / www.irrodl.org/index.php/irrodl/article/ view/ 183/ 265

Russ-Eft. D., Bober. M.J ., De la Teja, I., Foxon, M.J ., \& Koszalka, T.A. (2008). Evaluator competencies. Standards for practice of evaluations in organizations. San Francisco, CA: J ossey-Bass.

Salmon, G. (2004). E-Actividades: El factor clave para una formación en línea activa. Barcelona: Editorial UOC.

Sangrá, A. \& González-Sanmamed, M. (2004) (Eds.). La transformación de las universidades a través de las TIC: discursos y prácticas. Barcelona: UOC.

Sangrà, A., González-Sanmamed, M., \& Romeu T. (2013). Online teaching faculty development in spain: challenges and current perspectives. Proceedings of the 2013 EDEN Annual Conference, Oslo, 12-15J une, 2013.

Singleton, E.S. (2004). Teaching online: The changing nature of faculty. In G. Richards (Ed.), Proceedings of World Conference on E-Learning in Corporate, Government, Healthcare, and Higher Education (pp. 951- 956). Chesapeake, VA: AACE. Retrieved J uly 30, 2014, from http:// www.editlib.org/noaccess/ 10989/

Spector, J.M. (2007) (Ed.). Finding your online voice: Stories told by experienced online educators. Mahwah, NewJ ersey: Lawrence Earlbaum Associates.

Turner, C. W. (2005). Voices of faculty and students: Exploring distance education at a state university. Unpublished doctoral dissertation. New Mexico State University: Las Cruces, NM.

Varvel, V.E. (2007). Master online teacher competencies. Online J ournal of Distance Learning Administration, 10(1). Retrieved August 31, 2013, from http:// www.westga.edu/\%7Edistance/ ojdla/ spring101/varvel101.pdf 
Williams, P.E. (2003). Roles and competencies for distance education programs in higher education institutions. American J ournal of Distance Education, 17(1), 45- 57. DOI: $10.1207 /$ S15389286AJ DE1701_4

(C) González-Sanmamed, Muñoz-Carril, Sangrà

\section{Athabasca University $\mathbf{A}$}

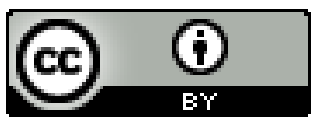

This work is licensed under a Creative Commons Attribution 4.0 International License. 